\title{
IAMJ
}

INTERNATIONAL

AYURVEDIC

MEDICAL JOURNAL

\section{NASYA IN SHALAKYA TANTRA}

\section{Deepa. M. Hugar'1, Veerayya Hiremath ${ }^{2}$, Gururaj ${ }^{3}$, Shashikala D K ${ }^{4}$}

${ }^{1}$ Second year PG Scholar, ${ }^{2}$ HOD \& Professor, ${ }^{3}$ Assistant Professor \& ${ }^{4}$ Associate Professor

Shree Jagadguru Gavisiddeshwara Ayurvedic Medical College, Koppal, Karnataka, India

Corresponding Author: deepahugar9495@gmail.com

\section{https://doi.org/10.46607/iamj4309082021}

(Published Online: August 2021)

Open Access

(C) International Ayurvedic Medical Journal, India 2021

Article Received: 02/08//2021 - Peer Reviewed: 11/08/2021 - Accepted for Publication: 12/08/2021

\section{Check for updates}

\section{ABSTRACT}

Shalakyatantra is one of the Ashtanga Ayurveda that deals with the treatment of diseases related to the eye, ear, nose, throat, oral cavity, head, and scalp through oral medications, kriyakalpa, Panchakarma procedures, surgical and para-surgical procedures, etc. Nasya is one among panchakarma; the intranasal method of drug administration meant for treatment and detoxification and is widely used in Shalakyatantra. It is said 'Nasa hi shiraso dwaram'; The nose is the gateway for drug administration for the ailments of head and organs situated in it viz, eye, ear, nose, throat, head, scalp, hair, and oral cavity. Nasya can be used also for the prevention of diseases, to strengthen the indriya (sense organs), and to bring Shiro laghuta by eliminating the doshas. This article is a compilation of references to Nasya used in shalakya tantra chikitsa.

Keywords: Nasya, Shalakya tantra, Panchakarma, eye, ear, nose, throat, head, scalp, oral cavity.

\section{INTRODUCTION}

Administration of medicine through the nasal route is known as nasya ${ }^{l}$. This treatment modality is used to eliminate the vitiated doshas which are responsible for producing disease. Shirovirechana, Shirovireka,
Murdhavirechana are the other names of this procedure $^{2}$. Ayurveda describes the nose as the doorway to the head. Nasya cleanses and opens the channels of the head, eyes, nose, ears, throat, and oral cavity and 
improves the oxygenation i.e., the flow of prana which has a direct and highly beneficial influence on brain functions. ${ }^{3}$

\section{INDICATIONS: ${ }^{4}$}

Shirastambha -Stiffness of Head, Gadgadavat - A Form of Dysarthria, Manyastambha - Stiffness of Neck, Dantaharsha - Hypersensitivity of Tooth, Dantastambha - Stiffness of Teeth, Chaladanta Mobility of Teeth, Dantashula - Toothache, Swarabheda - Hoarseness of Voice, Hanugraha - Rigidity of Mandibular Joint, Vakgraha - Dysarthria, Peenasa - Chronic Rhinitis, Dantapata - Falling of Teeth Galashundika - Elongated Uvula, Karnaksweda Tinnitus, Galashaluka - Adenoids, Keshapata - Hair Fall, Netra Roga - Eye disorders, Timira - Myopia, Vartmaroga - Diseases of Eyelids, Nasaroga - Nasal Disorders, Upajihiwika - Rannula/Cyst, Suryavarta - Frontal Sinusitis, Ardhawabhedaka - Migraine, Krimijashiroroga - Headache due to Krimi, Grivaroga - Disease of Neck, Vataja Shiroroga Headache due to Vata, Amsashula - Shoulder Pain, Mukhashosha - Dryness of Mouth, Mukharoga A Disorder of Mouth, Mukharoga - Oral Cavity Disorder, Palitya - Early Graying of Hair, Nidranasha Sleeplessness, Netragatasukraroga - Corneal Opacity, Vyanga - Pigmented Spots on Face, Karna Shula - Ear Ache, Akshishula - Painful Eyes, Shirashula Headache, Ardita - Cranial Nerve Palsies

\section{CONTRA-INDICATIONS: ${ }^{5}$}

Ajeerna - Indigestion, Peetasneha - The person who is subjected to oral snehana treatment, Peetamadya The person who is intoxicated due to alcohol, Virikta - Client subjected to Virechana Navajwara - Suffering from fever, Snatashira - After the head bath, Ksudhartha - Hungry Client, Trushnartha - Thirsty client, Ativyayama - Excessive exercise, Garbhini Pregnant women, Bhuktabhakta -After Meal, Vyayama klanta - Excessive physical work, Vyavaya klanta - Excessive sex indulging, Shokabhitapta- State of grief, Vriddha-Aged person, Bala- Children below the age of 7 years

Aims and Objectives: A collection of the description of Nasya in brihatrayi,laghutrayi, and related journals.

\section{PROCEDURE}

The procedure of administration of Nasya comprises

1. Purva karma ${ }^{6}$

2. Pradhana karma ${ }^{6}$

3. Paschat karma

1) Purvakarma: Selection of the patient: The patient should be selected according to the indications and contraindications of Nasya described in the classics.

\section{Preparation of the patient:}

- The patient who has passed his natural urges like urine, stool, etc. routine daily activities like bath, prayer, light breakfast, etc should be done. Now the patient gets ready for Nasya karma. He should lie down on Nasya Shayya.

- Before Nasya, Mridu Abhyanga should be done on scalp, forehead, face, and neck for 3 to 5 minutes by medicated oil like Ksheera Bala Taila, Panchaguna Taila, etc.

\section{2) Pradhana Karma:}

- The patient should lie down in a supine position with ease on Nasya Shayya. Shira should be "Pralambita" (lowered) and the foot part is to be slightly raised.

- The Head should not be excessively flexed or extended. If the head is not lowered, the nasal medication may not reach the desired distinction and if it is lowered too much, there may be the danger of getting the medication to be lodged in the brain.

- After covering the eyes with a clean cotton cloth, the physician should raise the tip of the patient's nose with his left thumb and with the right hand, the sukoshna medicine should be dropped in both the nostrils in a proper way.

\section{3) Paschat Karma:}

- The patient is asked to spit out the medicine that reaches the throat. Nadi Swedana to be given again after nasya. Gentle massage to be given on the forehead, palms and soles of the patient and allow to take rest.

- Then the patient is to be given dhumapana, followed by kavalagraha or gandusha which eliminates Kapha. 
- Then the patient is advised to follow a wholesome diet, resort to the breezeless, warm residence and observe self-restraint. Day sleeping and cold water for any purpose like Pana, Snana, etc. should be avoided.

\section{Nasya classification:}

Mainly classified into 2 types

1. Shodhana

2. Shamana

According to charaka acharya 5 types ${ }^{8}$
1. Navana nasya

2. Avapeedana nasya

3. Dhmapana nasya

4. Dhuma nasya

5. Pratimarsha nasya

1. Navana nasya : Navana is instillation of medicated taila or Ghrita into the nose ${ }^{9}$.

Ex : Kaphajanyatimira - Triphaladi taila ${ }^{10}$ All type of nasa roga-Shadbindu taila nasya ${ }^{11}$

\begin{tabular}{|c|c|c|c|}
\hline Sl.no & Disease & Nasya dravya & Reference \\
\hline 1. & Kaphaja rohini & $\begin{array}{l}\text { Taila prepared of } \\
\text { Swetha aparajita, Dantimula, Vayu } \\
\text { vidanga \& Saindhava lavana } \\
\text { Apamarga beeja }\end{array}$ & A H U 22/62 \\
\hline 2. & Krimidanta & $\begin{array}{l}\text { Snigdha nasya } \\
\text { Taila prepared with vidarikanda, yasti, } \\
\text { shringataka, kesara }\end{array}$ & $\begin{array}{l}\text { A } H U 22 / 19 \\
\text { A } H U 22 / 25\end{array}$ \\
\hline 3. & Vaidarbha & Sheetala nasya & A H U $22 / 29$ \\
\hline 4. & Upakusha & Madhura ganasadhita ghrita sidda nasya & A H U 22/31-32 \\
\hline 5. & Saushira & $\begin{array}{l}\text { Taila prepared with kamala, krishnasarivaka- } \\
\text { laagaru, Raktachandana, yasti, patanilodra, } \\
\text { misri, pundarika }\end{array}$ & A H U 22/36 \\
\hline 6. & Talushosha & Dhanwamamsa snigdha ksheerasarpi & A H U $22 / 54$ \\
\hline 7. & All types of mukharoga & $\begin{array}{l}\text { Vata nashaka Madhuraskandha siddha taila } \\
\text { nasya }\end{array}$ & A H U 22/55 \\
\hline 8. & Vataja rohini & Taila nasya & A H U 22/59 \\
\hline 9. & Vataja shirashula & $\begin{array}{l}\text { Taila prepared with varunadi gana dravya } \\
\text { and Madhura gana dravya }\end{array}$ & A H U 24/4 \\
\hline 10. & Pittaja shiroroga & $\begin{array}{l}\text { Snehadravya : Goghrita } \\
\text { Dravadravya : Goksheera } \\
\text { Kalkadravya : jivaniya varga dravyakalka }\end{array}$ & A H U 24/11 \\
\hline 11. & Vatapittaja shiroroga & $\begin{array}{l}\text { Taila prepared with jivaka, vrushabaka, } \\
\text { draksha, sita, yastimadhu, bala, Utpala }\end{array}$ & $\begin{array}{l}\text { Vangasenashirorogaadhikara } \\
/ 81\end{array}$ \\
\hline 12. & Krimija shiroroga & $\begin{array}{l}\text { Vidanga taila nasya } \\
\text { Taila prepared with vayuvidanga, bijaka, } \\
\text { danti, hingu }\end{array}$ & $\begin{array}{l}\text { Vangasenashirorogaadhikara } \\
/ 88\end{array}$ \\
\hline 13. & Krimija shiroroga & $\begin{array}{l}\text { Apamarga taila nasya } \\
\text { Taila prepared with apamarg bija, trikatu, } \\
\text { haldi, hing, vayuvidanga, and Gomutra }\end{array}$ & $\begin{array}{l}\text { Vangasenashirorogaadhikara } \\
\text { / } 89\end{array}$ \\
\hline 14. & Suryavarta & Ksheera Ghrita nasya & $\begin{array}{l}\text { Vangasenashirorogaadhikara } \\
191\end{array}$ \\
\hline 15. & & $\begin{array}{l}\text { Taila prepared with bhringaraja swarasa and } \\
\text { yastimadhu }\end{array}$ & $\begin{array}{l}\text { Vangasenashirorogaadhikara } \\
194\end{array}$ \\
\hline 16. & Pakshmashata & $\begin{array}{l}\text { Swadu sheetaskandha sadhita sarpi navana } \\
\text { nasya }\end{array}$ & A S UT $12 / 6$ \\
\hline
\end{tabular}




\begin{tabular}{|c|c|c|c|}
\hline 17. & Vataja abhishyanda & $\begin{array}{l}\text { A) Snehadravya - taila } \\
\text { Dravadravya - goksheera } \\
\text { Kalka dravya - Madhura gana dravya } \\
\text { B) Snehadravya - taila } \\
\text { Dravadravya - ksheera } \\
\text { Kalkadravya - Rasna, Abhiru, Dashamula, } \\
\text { Bala, kola, Kulatta, and yava }\end{array}$ & A S UT 19/8 \\
\hline 18. & Raktajaabhishyanda & $\begin{array}{l}\text { C) Sneha dravya - Ghritamanda } \\
\text { Dravadravya -Breastmilk } \\
\text { Kalkadravya - powders of sugar, Madhuka, } \\
\text { Nilotpala }\end{array}$ & A S UT 19/40 \\
\hline 19. & Timira & $\begin{array}{l}\text { A) Oil processed in an iron vessel with the } \\
\text { decoction of asana and Bhringaraja swarasa } \\
\text { B)Goshakrith taila Nasya-oil processed with } \\
\text { the decoction of cow dung is useful for Nasya } \\
\text { C)oil processed with tilataila-1 lit } \\
\text { Shunti churna }-125 \mathrm{gm} \\
\text { Yasti churna }-125 \mathrm{gm} \\
\text { Bhringaraja swarsa -4lit }\end{array}$ & A S UT 19/44 \\
\hline 20. & $\begin{array}{l}\text { All types of Netrarogas } \\
\text { Mukhadaantagreevabalaprada } \\
\text { Kantiprada }\end{array}$ & $\begin{array}{l}\text { Jivanti taila prayoga } \\
\text { Roots of jivanti } \\
\text { Sneha dravya :tilataila } 1 \text { prasta } \\
\text { Dravadravya : goksheera } \\
\text { Kalkadravya :jivanti } 1 \text { pala } \\
\text { Shatavari } 1 \text { pala } \\
\text { Yasti } 4 \text { pala } \\
\text { Prepare taila in loha patra } \\
\text { Then kept prepared taila in loha patra }\end{array}$ & A H UT 13/41,42,43 \\
\hline 21. & $\begin{array}{l}\text { All type of urdwajatrugata vyad- } \\
\text { hiand vatakaphajanetra roga }\end{array}$ & $\begin{array}{l}\text { Snehadravya-tila taila } \\
\text { Dravadravya-Goksheera } \\
\text { Kalka Dravya- Swethaerand,vanabhanda, } \\
\text { Triphala, devadaru, bala, vacha, tagara, } \\
\text { ghosha, pathabeda, bilwamula make it into } \\
\text { tailpaka. } \\
\text { Use as nasya } \\
\text { - } \\
\text { Snehadravaya: Goksheera } \\
\text { Drava dravya; Dashamulakwatha } \\
\text { Kalka dravya :Netrabala (HRUBERA) } \\
\text {,devadaru, nishi,daruhaldi,pippali }\end{array}$ & A H UT $13 / 46$ \\
\hline 22. & Sannipataja timira & $\begin{array}{l}\text { Taila prepared with Madhuka, vidanga, } \\
\text { devadaru }\end{array}$ & A H U 13/75 \\
\hline 23. & Kaphaja timira & $\begin{array}{l}\text { Triphaladi taila } \\
\text { Taila prepared with Triphala, Lodra, Usira, } \\
\text { Phalapriyangu }\end{array}$ & $\begin{array}{l}\text { Vangasenanetrarogaadhikara } \\
/ 425\end{array}$ \\
\hline 24. & Pittaja timira & $\begin{array}{l}\text { Gomaya taila } \\
\text { Taila prepared with Goshakrith. }\end{array}$ & $\begin{array}{l}\text { Vangasenanetrarogaadhikara } \\
\text { / } 426\end{array}$ \\
\hline
\end{tabular}




\begin{tabular}{|c|c|c|c|}
\hline 25 . & Peenasa pratishyaya & $\begin{array}{l}\text { Taila prepared with Kalinga, Hingu, Mari- } \\
\text { cha, Laksha, Sursa, katphala, Kusta, Lodra, } \\
\text { Sigru, Vidanga }\end{array}$ & B.R $63 / 7$ \\
\hline 26. & Nasaarsha & $\begin{array}{l}\text { Taila prepared with Murchita tilataila, } \\
\text { Gruhadhuma, Pippali, Devadaru, Ya- } \\
\text { vakshara, Saindhava lavana, Shikaribeeja }\end{array}$ & B.R $63 / 33$ \\
\hline 27. & Badhirya & $\begin{array}{l}\text { Taila prepared with Dashamoolakwatha, } \\
\text { Dashamoolakalka, Murchitatila taila, }\end{array}$ & $B R 63 / 36$ \\
\hline 28. & $\begin{array}{l}\text { Karnanada, karnapratinaha, kar- } \\
\text { nashula, badhirya }\end{array}$ & $\begin{array}{l}\text { Madhukaditaila } \\
\text { Taila prepared with Murchitatilataila, } \\
\text { Madhuyashti, Dashamoola, Daruharid- } \\
\text { ra,Vacha, Kusta, Shigru, Rasanjana, devada- } \\
\text { ru, vidalavana, svarjakshara, saindhava la- } \\
\text { vana }\end{array}$ & $B R 63 / 69$ \\
\hline
\end{tabular}

\section{2 ) Avapeedana nasya}

Avapeedana nasya - It is a type of shodhana nasya Instillation of Fresh juice of pungent substance into the nose is called Avapidana nasya ${ }^{12}$
Drugs used are teekshanadravyas like saindhava, pippali, maricha etc.

ex : Galaroga, Akshiroga, Timira, Shiroroga, Nasaroga

\begin{tabular}{|c|c|c|c|}
\hline Sl no & Disease & Yoga & Reference \\
\hline 1 & Nasaroga & Gudanagara nasya & A S U 24/39 \\
\hline 2 & Dustapratishyaya & $\begin{array}{l}\text { Trikatu, indrayava, vidangasara, indrayava, jeeraka, saindha- } \\
\text { va lavana is macerated well in ajamutra }\end{array}$ & A S U 24/37 \\
\hline 3 & Putinasa & $\begin{array}{l}\text { Juice is prepared with hingu, trikatu, vatsaka, indrayava, } \\
\text { swetha punarnava, laksha, saurabha beeja, katphala, ugra, } \\
\text { vacha, kusta, shigrubeeja, vidanga, and karanja }\end{array}$ & Su ut $23 / 45$ \\
\hline 4 & $\begin{array}{l}\text { Kaphaja prat- } \\
\text { ishyaya }\end{array}$ & Katu Dravya nirmita dhuma nasya & Ch chi $26 / 138$ \\
\hline 5 & $\begin{array}{l}\text { Sarvaprakara } \\
\text { shiroroga }\end{array}$ & Swarasa from shunti and guda & $\begin{array}{l}\text { Vangasenashirorogaadhikara } \\
164\end{array}$ \\
\hline 6 & Suryavarta & Shunti swarasa, pippali, vacha & $\begin{array}{l}\text { Vangasenashirorogaadhikara } \\
/ 13\end{array}$ \\
\hline 7 & Sarvashiroroga & Hruswa shigru beeja, nilottita mix with gomutra & $\begin{array}{l}\text { Vangasenashirorogaadhikara } \\
\text { /77 }\end{array}$ \\
\hline 8 & Peenasa & $\begin{array}{l}\text { Kalinga(endraja), hingu, maricha, laksha swarasa, katphala, } \\
\text { kushta, saindhava lavana, trikatu, grinded with ushnajala }\end{array}$ & $\begin{array}{l}Y R \text { Nasaroga chikitsa adyaya } \\
/ I\end{array}$ \\
\hline
\end{tabular}

3)Pradhamana nasya /dhmapana nasya: It is a type of shodhana nasya where one kola quantity of fine powder is blown into nostrils ${ }^{13}$.

\begin{tabular}{|l|l|l|l|l|}
\hline SI no & Disease & Yoga & Reference \\
\hline 1 & $\begin{array}{l}\text { Kaphaja prat- } \\
\text { ishyaya }\end{array}$ & Fine powder of manashila,vacha, trikatu, hingu, guggulu & Ch chi $26 / 151$ \\
\hline 2 & $\begin{array}{l}\text { Naveen prat- } \\
\text { ishyaya }\end{array}$ & $\begin{array}{l}\text { Fine powder of Rohisha, Alaji, Tarkari, Choraka, twak, patra, } \\
\text { maricha, ela, upakunchanka }\end{array}$ & Ch chi 26/137 \\
\hline 3 & Pratishyaya & Kalika navasagara nasya & YR Nasaroga chikitsa \\
\hline
\end{tabular}




\begin{tabular}{|l|l|l|l|l|}
\hline & & $\begin{array}{l}\text { Fine powder of Navasagara, chunaka churna, an equal quantity } \\
\text { of gunja }\end{array}$ & adhyaya /71-72 \\
\hline 4 & Pratisyaya & $\begin{array}{l}\text { Chatur jataka churna nasya } \\
\text { Fine powder of twaki, ela, tejapatra, nagakesara }\end{array}$ & $\begin{array}{l}\text { YR } \\
\text { adhyaya /70 }\end{array}$ \\
\hline 5 & $\begin{array}{l}\text { Sannipataja shi- } \\
\text { rashula }\end{array}$ & $\begin{array}{l}\text { Smaraphaladi churna nasya } \\
\text { Fine powder of mounaphala, tilaparni, Raktachandana , leaves } \\
\text { of kushapatra, Jayapalabeeja. }\end{array}$ & $\begin{array}{l}\text { YR } \\
\text { adhyaya/43 }\end{array}$ \\
\end{tabular}

4 )Dhuma nasya: Medicated smoke inhaled through the nose and exhaled through the oral route ${ }^{14}$ is called dhuma nasya

\begin{tabular}{|l|l|l|l|}
\hline Sl no & Yoga & Disease & Reference \\
\hline 1 & $\begin{array}{l}\text { Shathwadi dhumavarti shathwa, twak, bala, kumkuma, shonaka, } \\
\text { erandamoola twak, aamlavetasa add vasa and Ghrita. }\end{array}$ & $\begin{array}{l}\text { Naveena } \\
\text { pratishyaya }\end{array}$ & Ch Si 9/92 \\
\hline 2 & $\begin{array}{l}\text { Vidanga, Saindhava Lavana, Guggulu, Manashila, Vacha } \\
\text { Pratishyaya }\end{array}$ & $\begin{array}{l}\text { YR Nasaroga } \\
\text { adhyaya/67 }\end{array}$ \\
\hline 3 & Vartis prepared with daruharidra, ingudi, danti, apamargaa, surasa & Pratishyaya & B.R 63/10 \\
\hline
\end{tabular}

5. Pratimarsha nasya : Instillation of oil into the nostrils is called pratimarsha nasya ${ }^{15}$. The dose of pratimarsha nasya is two bindu for each nostril.

A bindu is the quantity of the oil that drops from the index finger dipped into oil to the level of its first two phalanges.

\begin{tabular}{|c|c|c|c|}
\hline SI no & Yoga & Yoga & Reference \\
\hline 1 & Taila prepared with bibitaki, nimba, gambhari, siva, selu, kakini & Palita & $\begin{array}{l}\text { Sharangadhara samhita } \\
\text { nasya prakarana } 45\end{array}$ \\
\hline 3 & $\begin{array}{l}\text { Shadbindu taila Taila prepared with Murchita tila taila, ajamutra, } \\
\text { sunti, erandamoola twak, jivanti, rasna, tagara, vidariganda, yasti- } \\
\text { madhu, Saindhava lavana }\end{array}$ & $\begin{array}{l}\text { Sarva shiro- } \\
\text { roga } \\
\text { Kalitya }\end{array}$ & $\begin{array}{l}\text { Vangasena shirorogadhikara } \\
/ 76\end{array}$ \\
\hline
\end{tabular}

\section{Indication $^{16}$ ( Sharangadhara samhita,nasyaprakarana 45)}

Urdwajatru vikara

Kalitya

Palitya

Strengthen the sense organ

\section{Classification of nasya karma based on pharmacological action ${ }^{17}$}
A. Virechaniya nasya
Ex:

1.Shiroroga

2.Nasa roga

3.Galaroga

4.Galaganda

5.Swarabeda 
B. Tarpana /Brhamhana nasya

Indication

1.Suryavarta

2.Swarakshaya

3.Nasikashotha

4.Mukhashotha

5. Vaksanga

C. Shamananasya:

Ex:

1.Kesha palitya

2.Netraroga

\section{DISCUSSION}

Drug absorption in 'Nasya karma' is a complex process and depends upon drug properties, anatomical physiological conditions of the nasal cavity, and intranasal pathways.

The probable mode action of drugs of Nasya karma can be. Neurological Pathway- It may be through stimulation of the Olfactory nerve \& the Trigeminal nerve (Ophthalmic \& Maxillary branches). The peripheral olfactory nerves are chemoreceptors in nature. These nerves differ from other cranial nerves in their close relationship with the brain. These are connected with the higher centres of the brain i,e the limbic system, consisting mainly of the amygdaloidal complex, hypothalamus, epithalamus, anterior thalamic nuclei parts of basal ganglia, etc. So the administration of the drug here stimulates the higher centres of the brain which shows action on the regulation of endocrine \& nervous system functions. Diffusion of The Drug- Lipid soluble substances have a greater affinity for passive absorption through the cell walls of the nasal mucosa. Non-polar hydrophobic molecules diffuse through the lipid bilayer of the plasma membrane, into \& out of cells. Vascular Pathway: It is possible through the pooling of nasal venous blood into an inferior ophthalmic vein (which in turn pools into the facial vein) \& deep facial vein. The facial vein has no valves. It communicates freely with the intracranial circulation, not only at its commencements and by the supraorbital veins which are connected with the ophthalmic vein, a tributary of the deep facial vein, which communicates through the pterygoid plexus with the cavernous venous sinus. Such a pooling of blood from nasal veins to venous sinuses of the brain is more likely to occur in head lowering position due to gravity, the absorption of the drug into meninges and related intracranial organ is a point of consideration.

Drugs in the form of Nasya have a probable mode of entry in circulation, hence has a role in improving vision and relieving asthenopic symptoms as follows.

- By general blood circulation, after absorption

- Through mucous membrane. Direct pooling into venous sinuses of the brain

- Inferior ophthalmic veins. Absorption directly into the cerebrospinal fluid, As this medicine is absorbed in ophthalmic vessels it has its nourishing role in extraocular muscles and eye proper. Along with this antioxidant property have a role in maintaining tissue built. It also pacifies the aggravated Vata Dosha in the head and helps to normalize the function of the central nervous system by nourishing the nervous system and balancing the circulation of blood in the sense organs including the ear also.

\section{CONCLUSION}

It can be concluded that either the essence of Nasya or Nasyadravya is reaching the brain and acting on important centres controlling different neurological, endocrine, and circulatory functions and thus showing systemic effects. According to Charaka, Nasa is 
the gateway to Shirah. The drug is administered through the nose as Nasya reaches to mastishka and eliminates only the morbid doshas responsible for producing the disease. Nasya is a very important procedure to cure Urdhva Jatrugata Rogas. Nasya Kar$m a$ enhances the activity of sense organs and prevents diseases. Nasya Karma prevents khalitya and ensures growth of hair and alleviates diseases like Manyastambha, Shirah-shoola, Ardhavbhedhaka, nasanaha, krimidanta, timira, etc. Nasya Aushadha makes its way to the brain through the nasal passage and olfactory tract to stimulate. Something happens when provocation of Doshas takes place in Shirah due to the irritating effect of an administered drug increasing the blood circulation of the brain. So extra accumulated morbid doshas are expelled out from small blood vessels and ultimately these morbid doshas are thrown out by the nasal discharge, tears, and by salivation. From the anatomical point of view, there are no such direct pharmacodynamic considerations between the nose and cranial organs. Moreover, the blood-brain barrier is a strict security system in the human brain. The nose is used as a route of drug administration for inhalation of anaesthetic materials and certain decongestants for paranasal sinusitis.

\section{REFERENCES}

1. Prof G Srinivasa acharya, Panchakarma illustrated book, chaukamba Sanskrit pratistana Delhi, First edition 2006, Nasyakarma Page no: 405

2. Prof Sunil v joshi, Panchakarma 5 main procedure book, Banarasidas publishers, reprint 2005, Nasya karma Page no: 214

3. Sunil V Joshi, Ayurveda, and Panchakarma, Published by Motilal Banaras Publishers, Reprint Edition, 2005, Chapter 10, Panchakarma's five main procedures, Page no: 213

4. Charaka samhita, edited by jadav ji trikam ji acharya, published by chaukamba samskrit samstana reprint 2014,chapter no/sloka no - siddistana 2/22, page no:690

5. Charaka samhita, edited by jadav ji trikam ji acharya, published by chaukamba samskrit samstana reprint 2014, chapter no/sloka no - siddistana 2/20-21, page no: $689-690$
6. Dr B.A.Lohit Panchakarma book, chaukama orientalia ,First edition 2016 ,Nasya vidhiadyaya $7^{\text {th }}$ chapter, Page no:359

7. Dr G. Shrinivas Acharya, Panchakarma Illustrated, Published by Chaukhamba Sanskrit Pratishthan, Delhi, $1^{\text {st }}$ Edition, 2006, Nasya Karma, Page no: 417

8. Charaka samhita, edited by jadav ji trikam ji acharya, published by chaukamba samskrit samstana reprint 2014, chapter no/sloka no - siddistana 9/89, page no:722

9. Prof G shrinivasa acharya ,Panchakarma illustrated book,chaukamba Sanskrit pratistana Delhi, First edition 2006, Nasyakarma Page no: 405

10. Dr Rajiv kumar rao, vangasena samhita ,prachya prakashana varanasi, edition 2010, chapter netra roga chikitsa adyaya, page no: 598

11. Vaidya lakshmipati Shastri, Yoga Ratnakara, chaukamba prakashana Varanasi, Reprint 2013, chapter shiroroga chikitsa, page no : 338

12. Prof . K.R. Srikantamurthy, Sharngadhara Samhita, Chaukamba orientalia Varanasi, Reprint 2012, chapter no/sloka no - 8/12, page no :224

13. Prof . K.R. Srikantamurthy, Sharngadhara Samhita, Chaukamba orientalia Varanasi, Reprint 2012 , chapter no/sloka no - 8/13, page no :224

14. Prof G shrinivasa acharya , Panchakarma illustrated book,chaukamba Sanskrit pratistana Delhi, First edition 2006, Nasya karma Page no: 40

15. Prof . K.R. Srikantamurthy, Chaukambaorientalia Varanasi , Reprint 2012, chapter no/sloka no $-8 / 38$, page no :227

16. Prof . K.R. Srikantamurthy ,Chaukambaorientalia Varanasi , Reprint 2012 , chapter no/sloka no $-8 / 45$, page no :227

17. Dr Brahmananda Tripathi, Astanga hrudayam Hindi commentary, Chaukamba Sanskrit pratistana Delhi, Reprinted 2012, chapter no/sloka no - 20/4,5,6, page no: 227

\section{Source of Support: Nil \\ Conflict of Interest: None Declared}

How to cite this URL: Deepa. M. Hugar et al: Nasya In Shalakya Tantra. International Ayurvedic Medical Journal \{online\} 2021 \{cited August 2021\} Available from: http://www.iamj.in/posts/images/upload/1874_1881.pdf 